\title{
Influence of FYM and Gypsum on Growth and Seed Yield in Carrot (Daucus carota L.) Irrigated with High RSC Water
}

\author{
Amit Kumar ${ }^{1}$, Vinod Kumar Batra', Vijaypal Singh Panghal', \\ Axay Bhuker ${ }^{2}$ and Rajesh Kumar ${ }^{1^{*}}$ \\ ${ }^{I}$ Department of Vegetable Science, CCS Haryana Agricultural University, \\ Hisar-125004, India \\ ${ }^{2}$ Department of Seed Science and Technology, CCS Haryana Agricultural University, \\ Hisar-125004, India \\ *Corresponding author
}

\begin{tabular}{|c|c|}
\hline \multicolumn{2}{|r|}{ A B S T R A C T } \\
\hline & \multirow{6}{*}{$\begin{array}{l}\text { A field experiment was conducted at Research Farm, Department of vegetable science, } \\
\text { CCS Haryana Agricultural University, Hisar during } 2015-16 \text { and } 2016-17 \text { to find out the } \\
\text { effect of high RSC water, FYM and gypsum on growth and seed yield of carrot (Daucus } \\
\text { carota L.). The cultivar used for the investigation was Hisar Gairic. The treatments } \\
\text { comprising three levels of FYM ( } 0,10 \text { and } 20 \text { t/ha) and gypsum }(0,50 \text { and } 100 \% \\
\text { neutralization of RSC) and its combinations were laid out in a factorial randomized block } \\
\text { design with three replications keeping a net plot size of } 3.0 \times 3.0 \mathrm{~m} \text {. The data were } \\
\text { recorded on various parameters, which were influenced by different levels of gypsum and } \\
\text { FYM. The minimum values for plant height, number of branches per plant, number of } \\
\text { different order umbels, seed yield, biological yield and harvest index were recorded in } \\
\text { control }\left(\mathrm{F}_{0} \mathrm{G}_{0}\right) \text {. The maximum values for growth and seed yield were recorded with } \\
\text { combination of FYM at } 20 \text { t/ha and } 100 \% \text { neutralization of RSC by gypsum in both the } \\
\text { years. The results suggest that the combination of FYM at } 20 \text { t/ha and } 100 \% \text { neutralization } \\
\text { of RSC by gypsum has shown the best treatment in carrot for higher seed yield with } \\
\text { quality seed production at commercial scale under semi-arid condition of Hisar (Haryana). }\end{array}$} \\
\hline & \\
\hline $\begin{array}{l}\text { Carrot, FYM, } \\
\text { gypsum, Growth, } \\
\text { Seed yield and RSC } \\
\text { water }\end{array}$ & \\
\hline Article Info & \\
\hline $\begin{array}{l}\text { Accepted: } \\
\text { 04 February } 2019 \\
\text { Available Online: } \\
10 \text { March } 2019\end{array}$ & \\
\hline & \\
\hline
\end{tabular}

\section{Introduction}

Carrot (Daucus carota L.) is a popular cool season root vegetable belongs to family Umbelliferae. It is cultivated in temperate countries during spring and summer season, while in tropical region during the winter season. There are two groups of varieties viz., the European type, which are biennial and Asiatic type being annual. The Asiatic types produce seed in the plains while the European type produce seed in hilly areas in India. The seed is the basic and most important input and has profound influence on the ultimate yield of the crop. In carrot, the demand for quality seed especially of Asiatic type is not only within the country but there are possibilities of export to other countries in tropical and sub-tropical regions where commercially seed is not produced. 
Currently, India's contribution in the world's total vegetable production is $13.6 \%$ and demand for vegetables is projected to rise to 170 million tons by the year 2025. In Haryana, the area under vegetable production is 4.1 lakh ha with an annual production of 60.23 lakh MT (Anonymous, 2015). The area and production of vegetables may be increased with proper management of poor quality of water. The area under carrot in India is fairly large and is grown in 86.00 thousand hectare with the production of 1350.00 thousand MT (Anonymous, 2017a). Carrot is also an important vegetable crop of Haryana. The area and production of carrot during 2016-17 was 26.49 thousand hectares and 372.12 thousand MT (Anonymous, 2017b), respectively. Among vegetable crops, the area of carrot is increasing every year and accordingly the demand of its quality seed for planting is also increasing faster.

Good quality water is the most vital and barely resource for drinking, agriculture and industry in the arid and semi-arid regions. In Haryana the ground water quality is $37 \%$ normal, $8 \%$ marginal and $55 \%$ of poor quality (Manchanda, 1976). High RSC water are characterized by their low EC $\left(<4 \mathrm{dSm}^{-1}\right)$, high SAR $\left[>10 \mathrm{mmol} / \mathrm{L}^{1 / 2}\right]$ and high RSC (>2.5 me/L) which constitute most important source of supplemental irrigation provided they are used judiciously and carefully. Such type of waters are found in vast areas of Rewari, Jhajjar, Bhiwani, Mahendergarh, Gurgoan, Sirsa, Kaithal, Hisar and Fatehabad districts of Haryana.

Moreover, the continuous use of sodic waters without amendments adversely affects the soil physico-chemical and microbiological properties of soil and at the same time, it adversely affects the mineral composition, uptake and yield of various crops under most situations (Ayers and Westcot, 1985, Oster and Jayawardene, 1998). Vegetable production is threatened by inadequate quality water, increasing soil salinity or alkalinity particularly in irrigated areas (FAO, 2001). The main reasons behind low productivity of vegetables may be poor quality water used for irrigation. In Haryana state on an average, $55 \%$ of ground water is of poor quality. In poor quality water, the proportion of sodic, saline and saline sodic water is 18,11 and 26\%, respectively (Manchanda, 1976). Continuous use of sodic water for irrigation without amendment may causes soil sodification and at the same time adversely affects the growth and yield of crops under most of the situations. Kaur et al., (2008) revealed that long term irrigation with sodic water may adversely affect quality of soil, microbial biomass carbon along with some physicochemical properties of the soil. Therefore, keeping in view of the importance of carrot crop, its seed demand and the availability of poor quality ground water for irrigation the present investigation was carried out.

\section{Materials and Methods}

The present study was conducted using the experimental units (plots) at the vegetable Research farm, CCS Haryana Agricultural University, Hisar. The soil of the experimental field was sandy loam Typicustochrept having $19.6 \%$ clay and CEC $9.3 \mathrm{C} \mathrm{mol} / \mathrm{kg}$ in $0-30 \mathrm{~cm}$ layer. The soil $\mathrm{pH}$ ranged between (7.6 and 9.6) and ESP values had a wide variation (12.9 to 43.5) among the plots with and without gypsum. The experimental treatments were laid out in randomized block design (RBD) with three replications having three levels of FYM and gypsum each. Different growth parameters analyzed during the study includes plant height, number of branches per plant, number of different order umbels, seed yield, biological yield and harvest index. Statistical analysis of data collected during the study 
was done by applying the technique of analysis of variance (ANOVA) as suggested by Gomez and Gomez (1984) and Panse and Sukhatme (1961). All the statistical analysis was carried out by using OPSTAT statistical software.

\section{Results and Discussion}

\section{Plant height}

The data on plant height were recorded at 60 , 90days and harvest after planting of stecklings presented in Table 1-3 clearly revealed that the various levels of FYM and gypsum significantly influenced the plant height. According to pooled data with increase in the FYM levels from 0 to $20 \mathrm{t} / \mathrm{ha}$ increased the plant height significantly from 65.60 to $92.33,82.57$ to 108.32 and 92.92 to $123.71 \mathrm{~cm}$, respectively. Similarly increase in gypsum application from 0 to $100 \%$ neutralization of RSC also increased the plant height from 60.17 to $94.39,76.67$ to 110.65 and 88.11 to $124.15 \mathrm{~cm}$, respectively.

The interaction effect of FYM and gypsum application was also found significant. Among all the interaction combinations maximum plant height $112.32,126.68$ and $143.97 \mathrm{~cm}$, respectively were observed with 20t/ha FYM and $100 \%$ neutralization of RSC, while the minimum 50.79, 70.66 and 79.28 $\mathrm{cm}$, respectively were obtained with control, where no FYM and gypsum was applied at 60, 90 days and harvest. Similar trend of observations were recorded during both the year of studies. It might be due to the application of gypsum and FYM could be attributed to minimizing the harmful effect of sodicity and increased nutrient availability as well better growth conditions. These results are in accordance with the findings of kumar et al., (2016) in onion, Uddain et al., (2010) in radish and Ahmed et al., (2014) in carrot.

\section{Number of branches at final harvest}

The data on number of branches at final harvest presented in Table 4 clearly revealed that the various levels of FYM and gypsum significantly affected the number of branches per plant. According to pooled data with increase in the FYM levels from 0 to 20 t/ha increased the number of branches significantly from 6.09 to 7.42. Similarly increase in gypsum application from 0 to $100 \%$ neutralization of RSC also increased the number of branches from 5.91 to 7.2. However, the interaction effect of FYM and gypsum application was found nonsignificant. Among all the interaction combinations maximum number of branches 8.18 was observed with 20t/ha FYM and $100 \%$ neutralization of RSC, while the minimum 5.32 was obtained with control, where no FYM and gypsum was applied. Similar trend of observations were recorded during both the year of studies. The number of branches per plant also increased with the application of FYM and gypsum. These results are in conformity with the findings of Hisham et al., 2014 in okra, Singh et al., (2008) in bottlegourd and Tripathi et al., (2013) in coriander.

\section{Days to $50 \%$ flowering}

The data on days to $50 \%$ flowering depicted in Table 5 showed that the various levels of FYM and gypsum significantly influenced the days to $50 \%$ flowering. According to pooled data with increase in the FYM levels from 0 to $20 \mathrm{t} / \mathrm{ha}$ increased the days to $50 \%$ flowering significantly from 55.59 days to 60.51 days. Similarly increase in gypsum application from 0 to $100 \%$ neutralization of RSC also increased the days to $50 \%$ flowering from 54.67 days to 61.04 days. The interaction effect of FYM and gypsum application was also found significant. Among all the interaction combinations 
maximum days to $50 \%$ flowering 63.14 days was observed with 20t/ha FYM and 100\% neutralization of RSC, while the minimum 53.35 days was obtained with control, where no FYM and gypsum was applied. It might be due to stress condition the days came earlier in control and in $\mathrm{F}_{2} \mathrm{G}_{2}$ came later due to neutralization of RSC, the plants showed full vegetative and reproductive phase. The results are in accordance with Tripathi et al., (2013) in coriander and Upadhyay et al., (2012) in Ammi majus L. observed the similar results.

\section{Number of first order umbels per plant}

Data on number of first order umbels per plant presented in Table 6 clearly revealed that the various levels of FYM and gypsum significantly influenced the number of first order umbels. According to pooled data with increase in the FYM levels from 0 to $20 \mathrm{t} / \mathrm{ha}$ increased the number of first order umbels significantly from 6.39 to 8.20. Similarly increase in gypsum application from 0 to $100 \%$ neutralization of RSC also increased the number of first order umbels from 6.24 to 8.14. However, the interaction effect of FYM and gypsum application was found nonsignificant. Among all the interaction combinations maximum number of first order umbels 9.15 was observed with 20t/ha FYM and $100 \%$ neutralization of RSC, while the minimum 5.34 was obtained with control, where no FYM and gypsum was applied. This might be due to fact that the gypsum had neutralized the sodicity effect of water and FYM in general improved the physical properties like structure of soil and thus increased growth of plants. Singh (1996) in carrot, Singh (2013) and Tripathi et al., (2013) in coriander also reported similar results.

\section{Number of second order umbels per plant}

The data on number of second order umbels per plant presented in Table 7 clearly revealed that the various levels of FYM and gypsum significantly influenced the number of second order umbels. According to pooled data with increase in the FYM levels from 0 to $20 \mathrm{t} / \mathrm{ha}$ increased the number of second order umbels significantly from 10.13 to 14.93 . Similarly increase in gypsum application from 0 to $100 \%$ neutralization of RSC also increased the number of second order umbels from 9.16 to 14.56. The interaction effect of FYM and gypsum application was found significant. Among all the interaction combinations maximum number of second order umbels 17.93 was observed with $20 \mathrm{t} / \mathrm{ha}$ FYM and $100 \%$ neutralization of RSC, while the minimum 8.06 was obtained with control, where no FYM and gypsum was applied. Similar trend of observations were recorded during both the year of studies. This might be due to fact that the gypsum had neutralized the sodicity effect of water and FYM in general improved the physical properties like structure of soil and thus increased growth of plants. These results are in conformity with the findings of Khoja (2004), Singh (2013), Tripathi et al., (2013) in coriander and Kumari et al., (2009) in carrot.

\section{Seed yield $\mathrm{q} / \mathrm{ha}$}

The data on total seed yield $\mathrm{q} /$ ha presented in Table 8 clearly showed that the various levels of FYM and gypsum significantly influenced the total seed yield. According to pooled data with increase in the FYM levels from 0 to 20 $\mathrm{t} /$ ha increased the total seed yield significantly from 1.98 (q/ha) to 4.08 (q/ha). Similarly increase in gypsum application from 0 to $100 \%$ neutralization of RSC also increased total seed yield from $1.75(\mathrm{q} / \mathrm{ha})$ to 4.10 (q/ha). The interaction effect of FYM and gypsum application was found significant. Among all the interaction combinations maximum total seed yield 5.49 (q/ha) was observed with 20t/ha FYM and 100\% neutralization of RSC, while the minimum 
1.31 (q/ha) was obtained with control, where no FYM and gypsum was applied. This might be due to fact that the gypsum had neutralized the sodicity effect of water. The farmyard manure seems to act directly by increasing the crop yield either by accelerating the respiratory process through cell permeability or by hormone growth action. It supplies nitrogen, phosphorus and sulphur in available forms to the plants through biological decomposition. Indirectly, it improves the nutrient uptake as well as physical properties of soil such as aggregation, aeration, permeability and water holding capacity (Chandramohan, 2002). The seed yield with gypsum as well as FYM application showed a significant increasing trend. Kaswan et al., (2013) in onion, Singh et al., (2008) in bottle gourd and Vithwel and Kanaujia (2013) in carrot also observed the similar effect of gypsum and FYM.

Table.1 Effect of high RSC water, FYM and gypsum on plant height $(\mathrm{cm})$ at 60 days after planting of stecklings

\begin{tabular}{|c|c|c|c|c|c|c|c|c|c|c|c|c|}
\hline \multirow[t]{2}{*}{ FYM } & \multicolumn{4}{|c|}{60 DAP (2015-16) } & \multicolumn{4}{|c|}{60 DAP (2016-17) } & \multicolumn{4}{|c|}{ pooled } \\
\hline & $\mathbf{G}_{\mathbf{0}}$ & $\mathbf{G}_{1}$ & $\mathbf{G}_{2}$ & Mean & $\mathbf{G}_{\mathbf{0}}$ & $\mathbf{G}_{1}$ & $\mathbf{G}_{2}$ & Mean & $\mathbf{G}_{\mathbf{0}}$ & $\mathbf{G}_{\mathbf{1}}$ & $\mathbf{G}_{2}$ & Mean \\
\hline$F_{0}$ & 50.04 & 65.20 & 78.20 & 64.48 & 51.53 & 67.12 & 81.46 & 66.70 & 50.79 & 66.16 & 79.83 & 65.60 \\
\hline $\mathbf{F}_{1}$ & 61.41 & 82.60 & 90.28 & 78.10 & 63.18 & 84.00 & 91.77 & 79.65 & 62.29 & 83.30 & 91.03 & 78.87 \\
\hline $\mathbf{F}_{2}$ & 67.39 & 95.27 & 110.13 & 90.93 & 67.48 & 99.17 & 114.51 & 93.72 & 67.44 & 97.22 & 112.32 & 92.33 \\
\hline Mean & 59.61 & 81.02 & 92.87 & & 60.73 & 83.43 & 95.91 & & 60.17 & 82.23 & 94.39 & \\
\hline $\begin{array}{c}\text { CD at } \\
5 \%\end{array}$ & \multicolumn{4}{|c|}{$\begin{array}{l}\text { Gypsum =1.60 } \\
\text { FYM= } 1.60\end{array}$} & \multicolumn{4}{|c|}{$\begin{array}{l}\text { Gypsum =2.31 } \\
\text { FYM= } 2.31 \\
\text { Gypsum x FYN }\end{array}$} & \multicolumn{4}{|c|}{$\begin{array}{l}\text { Gypsum }=1.42 \\
\text { FYM= } 1.42 \\
\text { Gypsum x FYl }\end{array}$} \\
\hline
\end{tabular}

Table.2 Effect of high RSC water, FYM and gypsum on plant height $(\mathrm{cm})$ at 90 days after planting of stecklings

\begin{tabular}{|c|c|c|c|c|c|c|c|c|c|c|c|c|}
\hline \multirow[t]{2}{*}{ FYM } & \multicolumn{4}{|c|}{90 DAP (2015-16) } & \multicolumn{4}{|c|}{90 DAP (2016-17) } & \multicolumn{4}{|c|}{ pooled } \\
\hline & $\mathbf{G}_{\mathbf{0}}$ & $\mathbf{G}_{1}$ & $\mathbf{G}_{2}$ & Mean & $\mathbf{G}_{\mathbf{0}}$ & $\mathbf{G}_{1}$ & $\mathbf{G}_{2}$ & Mean & $\mathbf{G}_{\mathbf{0}}$ & $\mathbf{G}_{1}$ & $\mathbf{G}_{2}$ & Mean \\
\hline $\mathbf{F}_{\mathbf{0}}$ & 69.24 & 79.71 & 95.28 & 81.41 & 72.08 & 81.91 & 97.21 & 83.73 & 70.66 & 80.81 & 96.25 & 82.57 \\
\hline $\mathbf{F}_{1}$ & 76.39 & 101.41 & 107.80 & 95.20 & 77.43 & 104.45 & 110.26 & 97.38 & 76.91 & 102.94 & 109.03 & 96.29 \\
\hline $\mathbf{F}_{2}$ & 81.27 & 114.70 & 124.00 & 106.66 & 83.58 & 116.98 & 129.36 & 109.98 & 82.43 & 115.84 & 126.68 & 108.32 \\
\hline Mean & 75.63 & 98.61 & 109.03 & & 77.70 & 101.11 & 112.28 & & 76.67 & 99.86 & 110.65 & \\
\hline $\begin{array}{l}\text { CD at } \\
5 \%\end{array}$ & \multicolumn{4}{|c|}{$\begin{array}{l}\text { Gypsum =1.49 } \\
\text { FYM= } 1.49\end{array}$} & \multicolumn{4}{|c|}{$\begin{array}{l}\text { Gypsum }=1.71 \\
\text { FYM }=1.71\end{array}$} & $\begin{array}{l}\text { Gypsu } \\
\text { FYM= } \\
\text { Gypsu }\end{array}$ & $\begin{array}{l}n=1.41 \\
1.41 \\
\times \mathrm{FYM}\end{array}$ & & \\
\hline
\end{tabular}


Table.3 Effect of high RSC water, FYM and gypsum on plant height $(\mathrm{cm})$ at harvest

\begin{tabular}{|c|c|c|c|c|c|c|c|c|c|c|c|c|}
\hline \multirow[t]{2}{*}{ FYM } & \multicolumn{4}{|c|}{$\begin{array}{l}\text { Plant height at harvest } \\
\qquad(2015-16)\end{array}$} & \multicolumn{4}{|c|}{$\begin{array}{c}\text { Plant height at harvest } \\
\text { (2016-17) }\end{array}$} & \multicolumn{4}{|c|}{ pooled } \\
\hline & $\mathbf{G}_{\mathbf{0}}$ & $\mathbf{G}_{1}$ & $\mathbf{G}_{2}$ & Mean & $\mathbf{G}_{\mathbf{0}}$ & $\mathbf{G}_{1}$ & $\mathbf{G}_{2}$ & Mean & $\mathbf{G}_{\mathbf{0}}$ & $\mathbf{G}_{1}$ & $\mathbf{G}_{2}$ & Mean \\
\hline $\mathbf{F}_{0}$ & 78.33 & 91.50 & 105.98 & 91.94 & 80.22 & 93.51 & 107.95 & 93.89 & 79.28 & 92.51 & 106.97 & 92.92 \\
\hline $\mathbf{F}_{1}$ & 88.70 & 109.77 & 120.60 & 106.36 & 91.01 & 111.83 & 122.44 & 108.42 & 89.86 & 110.80 & 121.52 & 107.39 \\
\hline $\mathbf{F}_{2}$ & 93.87 & 131.00 & 142.27 & 122.38 & 96.53 & 132.94 & 145.67 & 125.05 & 95.20 & 131.97 & 143.97 & 123.71 \\
\hline Mean & 86.97 & 110.76 & 122.95 & & 89.25 & 112.76 & 125.35 & & 88.11 & 111.76 & 124.15 & \\
\hline $\begin{array}{c}\text { CD at } \\
5 \%\end{array}$ & \multicolumn{4}{|c|}{$\begin{array}{l}\text { FYM= } 1.60 \\
\text { Gypsum } \times \text { FYM= } 2.78\end{array}$} & \multicolumn{4}{|c|}{$\begin{array}{l}\mathrm{FYM}=2.31 \\
\text { Gypsum } \times \mathrm{FYM}=4.00\end{array}$} & \multicolumn{4}{|c|}{$\begin{array}{l}F Y M=1.42 \\
\text { Gypsum } \times \text { FYM=2.46 }\end{array}$} \\
\hline
\end{tabular}

Table.4 Effect of high RSC water, FYM and gypsum on number of branches per plant at final harvest

\begin{tabular}{|c|c|c|c|c|c|c|c|c|c|c|c|c|}
\hline \multirow[t]{2}{*}{ FYM } & \multicolumn{4}{|c|}{ Number of branches (2015-16) } & \multicolumn{4}{|c|}{ Number of branches (2016-17) } & \multicolumn{4}{|c|}{ pooled } \\
\hline & $\mathbf{G}_{\mathbf{0}}$ & $\mathbf{G}_{1}$ & $\mathbf{G}_{2}$ & Mean & $\mathbf{G}_{\mathbf{0}}$ & $\mathbf{G}_{1}$ & $\mathbf{G}_{2}$ & Mean & $\mathbf{G}_{\mathbf{0}}$ & $\mathbf{G}_{1}$ & $\mathbf{G}_{2}$ & Mean \\
\hline $\mathbf{F}_{\mathbf{0}}$ & 5.00 & 5.80 & 6.40 & 5.73 & 5.64 & 6.55 & 7.15 & 6.45 & 5.32 & 6.17 & 6.78 & 6.09 \\
\hline $\mathbf{F}_{1}$ & 5.53 & 6.50 & 6.90 & 6.31 & 6.33 & 7.26 & 7.72 & 7.10 & 5.93 & 6.88 & 7.31 & 6.71 \\
\hline $\mathbf{F}_{2}$ & 6.07 & 7.20 & 7.77 & 7.01 & 6.86 & 8.01 & 8.59 & 7.82 & 6.47 & 7.61 & 8.18 & 7.42 \\
\hline Mean & 5.53 & 6.50 & 7.02 & & 6.28 & 7.27 & 7.82 & & 5.91 & 6.89 & 7.42 & \\
\hline $\begin{array}{c}\text { CD at } \\
5 \%\end{array}$ & \multicolumn{4}{|c|}{$\begin{array}{l}\text { Gypsum }=0.34 \\
\text { FYM=0.34 } \\
\text { Gypsum } \times \text { FYM= NS }\end{array}$} & \multicolumn{4}{|c|}{$\begin{array}{l}\text { Gypsum }=0.35 \\
\text { FYM=0.35 } \\
\text { Gypsum } \times \text { FYM= NS }\end{array}$} & \multicolumn{4}{|c|}{$\begin{array}{l}\text { Gypsum }=0.36 \\
\text { FYM=0.36 } \\
\text { Gypsum } \times \text { FYM=NS }\end{array}$} \\
\hline
\end{tabular}

Table.5 Effect of high RSC water, FYM and gypsum on days to 50\% flowering

\begin{tabular}{|c|c|c|c|c|c|c|c|c|c|c|c|c|}
\hline \multirow[t]{2}{*}{ FYM } & \multicolumn{4}{|c|}{$\begin{array}{c}\text { Days to } 50 \% \text { flowering } \\
(2015-16)\end{array}$} & \multicolumn{4}{|c|}{$\begin{array}{c}\text { Days to } 50 \% \text { flowering } \\
(2016-17)\end{array}$} & \multicolumn{4}{|c|}{ Pooled } \\
\hline & $\mathbf{G}_{\mathbf{0}}$ & $\mathbf{G}_{1}$ & $\mathbf{G}_{2}$ & Mean & $\mathbf{G}_{\mathbf{0}}$ & $\mathbf{G}_{1}$ & $\mathbf{G}_{2}$ & Mean & $\mathbf{G}_{\mathbf{0}}$ & $\mathbf{G}_{1}$ & $\mathbf{G}_{2}$ & Mean \\
\hline $\mathbf{F}_{\mathbf{0}}$ & 54.13 & 56.40 & 58.89 & 56.47 & 52.55 & 54.45 & 57.12 & 54.71 & 53.35 & 55.43 & 58.01 & 55.59 \\
\hline $\mathbf{F}_{1}$ & 55.93 & 61.17 & 62.83 & 59.98 & 54.05 & 59.29 & 61.08 & 58.14 & 54.99 & 60.23 & 61.96 & 59.06 \\
\hline $\mathbf{F}_{2}$ & 56.59 & 63.90 & 64.33 & 61.61 & 54.76 & 61.50 & 61.95 & 59.40 & 55.67 & 62.70 & 63.14 & 60.51 \\
\hline Mean & 55.55 & 60.49 & 62.02 & & 53.79 & 58.41 & 60.05 & & 54.67 & 59.45 & 61.04 & \\
\hline CD at $5 \%$ & \multicolumn{4}{|c|}{$\begin{array}{l}\text { Gypsum }=1.48 \\
\text { FYM }=1.48\end{array}$} & \multicolumn{4}{|c|}{$\begin{array}{l}\text { Gypsum =1.19 } \\
\text { FYM= } 1.19 \\
\text { Gvpsum x FYM }\end{array}$} & \multicolumn{4}{|c|}{$\begin{array}{l}\text { Gypsum =1.13 } \\
\text { FYM=1.13 } \\
\text { Gypsum } \times \text { FYM=1.96 }\end{array}$} \\
\hline
\end{tabular}


Table.6 Effect of high RSC water, FYM and gypsum on number of first order umbels/ plant

\begin{tabular}{|c|c|c|c|c|c|c|c|c|c|c|c|c|}
\hline \multirow[t]{2}{*}{ FYM } & \multicolumn{4}{|c|}{$\begin{array}{l}\text { Number of first order } \\
\text { umbels (2015-16) }\end{array}$} & \multicolumn{4}{|c|}{$\begin{array}{l}\text { Number of first order } \\
\text { umbels (2016-17) }\end{array}$} & \multicolumn{4}{|c|}{ Pooled } \\
\hline & $\mathbf{G}_{0}$ & $\mathbf{G}_{1}$ & $\mathbf{G}_{\mathbf{2}}$ & Mean & $\mathbf{G}_{0}$ & $\mathbf{G}_{1}$ & $\mathbf{G}_{2}$ & Mean & $\mathbf{G}_{\mathbf{0}}$ & $\mathbf{G}_{1}$ & $\mathbf{G}_{2}$ & Mean \\
\hline$F_{0}$ & 5.10 & 6.63 & 6.80 & 6.18 & 5.58 & 6.97 & 7.27 & 6.61 & 5.34 & 6.80 & 7.04 & 6.39 \\
\hline$F_{1}$ & 6.20 & 7.60 & 8.00 & 7.27 & 6.65 & 8.04 & 8.46 & 7.72 & 6.43 & 7.82 & 8.23 & 7.49 \\
\hline $\mathbf{F}_{2}$ & 6.97 & 8.30 & 8.90 & 8.06 & 6.92 & 8.73 & 9.39 & 8.35 & 6.94 & 8.52 & 9.15 & 8.20 \\
\hline Mean & 6.09 & 7.51 & 7.90 & & 6.38 & 7.91 & 8.38 & & 6.24 & 7.71 & 8.14 & \\
\hline $\begin{array}{c}\text { CD at } \\
5 \%\end{array}$ & \multicolumn{4}{|c|}{$\begin{array}{l}\text { Gypsum }=0.28 \\
\text { FYM }=0.28 \\
\text { Gypsum x FYN }\end{array}$} & \multicolumn{4}{|c|}{$\begin{array}{l}\text { Gypsum }=0.25 \\
\text { FYM }=0.25 \\
\text { Gypsum } \times \text { FYM= NS }\end{array}$} & \multicolumn{4}{|c|}{$\begin{array}{l}\text { Gypsum }=0.23 \\
\text { FYM }=0.23 \\
\text { Gypsum } \times \text { FYM= NS }\end{array}$} \\
\hline
\end{tabular}

Table.7 Effect of high RSC water, FYM and gypsum on number of second order umbels/ plant

\begin{tabular}{|c|c|c|c|c|c|c|c|c|c|c|c|c|}
\hline \multirow[t]{2}{*}{ FYM } & \multicolumn{4}{|c|}{$\begin{array}{c}\text { Number of second order } \\
\text { umbels (2015-16) }\end{array}$} & \multicolumn{4}{|c|}{$\begin{array}{l}\text { Number of second order } \\
\text { umbels (2016-17) }\end{array}$} & \multicolumn{4}{|c|}{ Pooled } \\
\hline & $\mathbf{G}_{\mathbf{0}}$ & $\mathbf{G}_{\mathbf{1}}$ & $\mathbf{G}_{2}$ & Mean & $\mathbf{G}_{0}$ & $\mathbf{G}_{1}$ & $\mathbf{G}_{\mathbf{2}}$ & Mean & $\mathbf{G}_{\mathbf{0}}$ & $\mathbf{G}_{1}$ & $\mathbf{G}_{\mathbf{2}}$ & Mean \\
\hline $\mathbf{F}_{\mathbf{0}}$ & 7.53 & 10.07 & 11.23 & 9.61 & 8.58 & 11.09 & 12.28 & 10.65 & 8.06 & 10.58 & 11.76 & 10.13 \\
\hline$F_{1}$ & 8.17 & 12.23 & 13.47 & 11.29 & 9.23 & 13.28 & 14.52 & 12.34 & 8.70 & 12.76 & 14.00 & 11.82 \\
\hline $\mathbf{F}_{2}$ & 10.20 & 15.60 & 17.40 & 14.40 & 11.27 & 16.65 & 18.45 & 15.46 & 10.74 & 16.13 & 17.93 & 14.93 \\
\hline Mean & 8.63 & 12.63 & 14.03 & & 9.69 & 13.67 & 15.08 & & 9.16 & 13.16 & 14.56 & \\
\hline $\begin{array}{c}\text { CD at } \\
5 \%\end{array}$ & \multicolumn{4}{|c|}{$\begin{array}{l}\text { Gypsum =0.24 } \\
\text { FYM=0.24 } \\
\text { Gypsum x FYN }\end{array}$} & \multicolumn{4}{|c|}{$\begin{array}{l}\text { Gypsum }=0.63 \\
\text { FYM }=0.63 \\
\text { Gypsum x FYM=1.10 }\end{array}$} & \multicolumn{4}{|c|}{$\begin{array}{l}\text { Gypsum }=0.42 \\
\text { FYM }=0.42 \\
\text { Gypsum x FYM= } 0.72\end{array}$} \\
\hline
\end{tabular}

Table.8 Effect of high RSC water, FYM and gypsum on total seed yield q/ha

\begin{tabular}{|c|c|c|c|c|c|c|c|c|c|c|c|c|}
\hline \multirow[t]{2}{*}{ FYM } & \multicolumn{4}{|c|}{$\begin{array}{l}\text { Seed yield q/ha } \\
\text { (2015-16) }\end{array}$} & \multicolumn{4}{|c|}{$\begin{array}{c}\text { Seed yield q/ha } \\
(2016-17)\end{array}$} & \multicolumn{4}{|c|}{ Pooled } \\
\hline & $\mathbf{G}_{\mathbf{0}}$ & $\mathbf{G}_{1}$ & $\mathbf{G}_{2}$ & Mean & $\mathbf{G}_{0}$ & $\mathbf{G}_{1}$ & $\mathbf{G}_{2}$ & Mean & $\mathbf{G}_{\mathbf{0}}$ & $\mathbf{G}_{1}$ & $\mathbf{G}_{2}$ & Mean \\
\hline $\mathbf{F}_{\mathbf{0}}$ & 1.22 & 1.93 & 2.60 & 1.92 & 1.26 & 2.02 & 2.71 & 2.00 & 1.31 & 1.98 & 2.66 & 1.98 \\
\hline$F_{1}$ & 1.70 & 3.26 & 4.12 & 3.03 & 1.75 & 3.32 & 4.16 & 3.08 & 1.73 & 3.29 & 4.14 & 3.05 \\
\hline $\mathbf{F}_{2}$ & 2.20 & 4.52 & 5.48 & 4.07 & 2.24 & 4.55 & 5.51 & 4.10 & 2.22 & 4.53 & 5.49 & 4.08 \\
\hline Mean & 1.71 & 3.24 & 4.07 & & 1.75 & 3.30 & 4.13 & & 1.75 & 3.27 & 4.10 & \\
\hline $\begin{array}{c}\text { CD at } \\
\mathbf{5 \%}\end{array}$ & \multicolumn{4}{|c|}{$\begin{array}{l}\text { Gypsum }=0.10 \\
\text { FYM }=0.10 \\
\text { Gynsum } \times \text { FYM }\end{array}$} & \multicolumn{4}{|c|}{$\begin{array}{l}\text { Gypsum }=0.12 \\
\text { FYM= } 0.12 \\
\text { Gypsum x FYN }\end{array}$} & \multicolumn{4}{|c|}{$\begin{array}{l}\text { Gypsum }=0.20 \\
\text { FYM= } 0.20 \\
\text { Gynsum } \times \text { FY }\end{array}$} \\
\hline
\end{tabular}

From the present investigation, it was concluded that the maximum increase in plant height, number of branches per plant, number of different order umbels, seed yield, biological yield and harvest index were observed in $100 \%$ neutralization of RSC and FYM @ 20 t/ha application while, minimum increase in plant height, number of branches 
per plant, number of different order umbels, seed yield, biological yield and harvest index were in no FYM and no gypsum treatment. Combined application of FYM and gypsum minimizes the adverse effect of sodic water and improve the soil properties also. Therefore, it can be concluded that for raising a successful seed crop of carrot under high RSC water condition application of FYM at $20 \mathrm{t} / \mathrm{ha}$ and gypsum at $100 \%$ neutralization will be helpful.

\section{References}

Ahmed, A., Sambo, B.E., Odion, E.C. and Arunah, U.L., 2014. Response of farmyard manure and inorganic fertilizers for sustainable yield of carrot (Daucus carota L.) in northern Nigeria. J. Agric. Vet. Sci., 7(2): 2633.

Anonymous, 2015. Database, Haryana Horticulture Department.

Anonymous. 2017a. Area and production of carrot in India during 2016-17. Data Year Book of National Horticulture Board, Gurgaon (Haryana) India.

Anonymous. 2017b. Area and Production of Vegetable Crops in Haryana during 2016-17. Directorate of Horticulture, Government of Haryana, Panchkula.

Ayers, R.S. and Westcot, D.W., 1985. Water quality for agriculture. Irrigation and Drainage, FAO, Rome. 29(1):174.

Chanramohan, S., 2002. Organic farming on cotton + black gram intercropping system. MSc Thesis, Department of Agronomy, TNAU Coimbatore, India.

FAO 2001. Climatic variability and change: A challenge for sustainable agriculture production. Committee on Agriculture. Sixteenth Session Report, 26-30 March, Rome, Italy.

Gomez, K.A. and Gomez, A.A., 1984. Statistical Procedure for Agricultural Research, $2^{\text {nd }}$ ed. John Wiley and
Sons, New York, USA.

Hisham, A., Prasad, V.M. and Saravanan, S., 2014. Effect of FYM on Growth, Yield and Fruits Quality of Okra (Abelmoschus esculentus. (L) Moench). IOSR J. Agric. Vet. Sci., 7(3):07-12.

Kaswan, P.K., Yadav, P.K. and Sharma, B.D., 2013. Response of Onion (Allium cepa L.) varieties to farm yard manure in arid region of western Rajasthan. Ann. of Hortic., 6(1): 30-34.

Kaur, J., Chaudhary, O.P. and Singh, B., 2008. Microbial biomass carbon and some soil properties as influenced by long term sodic water irrigation, gypsum and organic amendments. Aust. J. Soil Res., 46: 141-151.

Khoja, J.R. 2004. Effect of sowing time and sources of nitrogen on growth, thermal requirement, yield and quality of coriander [Coriandrum sativum L]. Ph.D. Thesis. Rajasthan Agricultural University Campus-

Kumar, A., Yadav, A.C. A., Kumar, V. and Singh, A., 2016. Evaluation of the effects of FYM and gypsum on onion (Allium cepa L.) production under sodic water irrigation. J. App. Nat. Sci,. 8(4): 1878-1883.

Kumari, B.V., Yadav, R.H. and Sowmya, M., 2009. A study on the effect of few eco-friendly manures on the growth attributes of carrot (Daucus carota L.). J Environ. Sci. Eng., 51(1):13-6.

Manchanda, H.R. 1976. Quality of ground waters in Haryana. Haryana Agri. Uni. Hisar, p. 160.

Oster, J.D. and Jayewardene, N.S., 1998. Agriculture management of sodic soil in sodic soils distribution processes, $\mathrm{p}$. 125-147. Management and Environmental Consequences (Eds. Summer, M.F. and Nadu, R.) Oxford Uni. Press, U.K.

Panse, V.G. and Sukhatme, P.V., 1961. 
Statistical Methods for Agricultural Workers. Indian Council of Agricultural Research, New Delhi, India, $381 \mathrm{p}$.

Singh, A. K. and Singh, A. K. 1996. Effect of nitrogen and potash on seed yield of carrot (Daucus carota L.) cv. Pusa Kesar. Crop Res., 12(2): 182-184.

Singh, A., Yadav, A.C., Brar, J.S., Sharma, S.K., and Phogat, V., 2008. Effect of FYM and gypsum on production of bottle gourd under sodic water conditions. Haryana J. Hortic. Sci., 37(3/4): 297-298.

Singh, S.P. 2013. Effect of biofertilizer Azospirillum on growth and yield parameters of coriander (Coriandrum sativum L.) cv. Pant haritima- Veg. Sci,. 40(1): 77-79.

Tripathi, M.L., Singh, H. and Chouhan,
S.V.S. 2013. Response of coriander (Cariandrum sativum L.) to integrated nutrient management. J. MultiDisciplinary Advance Res., 2(2): 4346.

Uddain, J., Chowdhury, S. and Rahman, M.J. 2010. Efficacy of different organic manures on growth and productivity of radish (Raphanus sativus L.). IJAEB, 3(2): 189-193.

Upadhyay, A., Tripathi, S. and Pandey, S.N., 2012. Effects of soil sodicity on growth, nutrients uptake and Biochemical responses of Ammi majus $\mathrm{L}$. Res. J. Soil Bio., 4(3): 69-80.

Vithwal and Kanaujia, S.P. 2013. Integrated nutrient management on productivity of carrot and fertility of soil. SAARC J. Agric., 11(2): 173-181.

\section{How to cite this article:}

Amit Kumar, Vinod Kumar Batra, Vijaypal Singh Panghal, Axay Bhuker and Rajesh Kumar. 2019. Influence of FYM and Gypsum on Growth and Seed Yield in Carrot (Daucus carota L.) Irrigated with High RSC Water. Int.J.Curr.Microbiol.App.Sci. 8(03): 337-345. doi: https://doi.org/10.20546/ijcmas.2019.803.042 